\title{
Challenges of Virtual Education during the COVID-19 Pandemic: Experiences of Mexican University Professors and Students
}

\author{
Claudia Patricia Contreras, David Picazo, \\ Aixchel Cordero-Hidalgo and Paola Margarita Chaparro-Medina \\ Autonomous University of Chihuahua, Chihuahua, México \\ https://orcid.org/0000-0003-4162-3055 \\ https://orcid.org/0000-0003-0521-6954 \\ https://orcid.org/0000-0001-9927-0972 \\ https://orcid.org/0000-0002-7270-9903
}

\begin{abstract}
Students' and university professors' challenges due to the COVID-19 worldwide pandemic have been enormous. Without prior notice, they had to switch from traditional education to virtual teaching. This study's objective was to identify the perception of students and professors of the Bachelor in the English Language from the University of Chihuahua, Mexico, during the transition to virtual classes due to the pandemic. Researchers applied a survey of 28 items with a Likert scale to 152 students during the spring semester 2020 and the second instrument of 51 items to 26 professors. The students reported having complications in connectivity $(21 \%)$ and difficulties interacting with professors and classmates (34\%). Many students reported experiencing anxiety $(69.1 \%)$ and feeling isolated (62.5\%). Most agree that they learn better in face-toface classes $(85 \%)$. In turn, the professors agree that the students had a lower performance than in a face-to-face semester (69.3\%). Despite this, the professors affirm that they followed the program to the letter (92.3\%) and completed the programmed contents $(84.6 \%)$. Besides, $92.3 \%$ of the academics are confident to face a new semester in virtual modality, if necessary. Although we can say that the transition from face-to-face to virtual classes in the institution was successful, students and professors encountered difficulties and disadvantages in the use of platforms for online classes. The benefit of this research's findings is understanding the University must have all the necessary elements in place for online teaching. It must establish a formal regulation of virtual programs that includes professor's and student's profile, as well as the strategies to be followed. The students' and professors' perceptions highlight the crucial elements that professors need to consider to teach virtual classes and take advantage of these lessons to face the future better.
\end{abstract}

Keywords: COVID-19; Virtual Learning Environment; university; education 


\section{Introduction}

In 2008 the United Nations Educational, Scientific and Cultural Organization (UNESCO), decided to implement the Information and Communication Technology (ICT) Competency Framework for Teachers having three versions: 2008,2011 , and 2018. It anticipates the predominating approach to the relationship between technology and education and includes recommendations for developing skills using current technologies.

The UNESCO, since the Qingdao Declaration (2015) affirmed it is crucial to include the ICT in educational policies and strategies to transform the learning process. It is necessary to rethink the professor's role and reform how the educational systems prepare, considering the opportunities that present online learning as a new pathway toward lifelong learning (UNESCO, 2015).Traditionally there was a list of functions and perceptions of the professor that has been historically and socially constructed, as shown in Figure 1. Experts should review this role, leading to a new pedagogical relationship because students demand professors to participate more and more in teaching with technologies. That is to say, to consider the technological dimension in the teaching profession. Technologies have emerged as a challenge for the link between professors and students, which causes a significant opportunity to review roles, functions, and holistically understand formal education and their professional performance (Casablancas, 2017).

\begin{tabular}{|c|c|}
\hline Barberá (2001) & $\begin{array}{l}\text { The professor has a collective knowledge that he/she must } \\
\text { share }\end{array}$ \\
\hline Castaño Garrido (2003) & The profesor has new teaching roles \\
\hline Cabero (2003) & The professor becomes a learning facilitator \\
\hline $\begin{array}{l}\text { García Martos (2009) \& Sangrá } \\
\text { \& González (2004) }\end{array}$ & $\begin{array}{l}\text { They explored professors' willingness to change their } \\
\text { culture and way of working to integrate technologies. }\end{array}$ \\
\hline Dorfsman (2012) & $\begin{array}{l}\text { The teaching profession is the backbone of future } \\
\text { generations. }\end{array}$ \\
\hline Labbas \& El Shaban (2013) & $\begin{array}{l}\text { Two types of teaching mentalities: necessary and not } \\
\text { necessary change in the teaching role }\end{array}$ \\
\hline Viñals \& Cuenca (2016) & A new way of learning and a new way of teaching \\
\hline
\end{tabular}

Figure 1. The conception of the professor's role (García Contador \& Gutiérrez Esteban, 2020)

Professors must adapt and train themselves to face the current times and contexts. This adaptation involves being flexible, dynamic, moving away from the traditional and tortuous for students, raising new forms of interaction and scenarios that include technologies for educational purposes (Cabrero \& Barroso, 2015). In recent months, the Coronavirus disease pandemic (COVID-19) caused by the SARS-CoV-2 virus rocked the entire world. On March 11, 2020, the World Health Organization (WHO) declared COVID-19 as a pandemic; by April 20, the same organism reports that many countries had reacted by asking their inhabitants to stay at home and restrict the movement of the population to reduce the virus transmission (WHO, 2020). WHO reported the first two cases in Mexico on February 29. 
According to UNESCO, by April 1 of year 2020, 185 countries had to close higher education institutions (HEI) activities, affecting 1,542,412,000 students, representing $89.4 \%$ of the total (UNESCO, 2020b). According to the University of Oxford, $70 \%$ of these countries finished the school semester with schools closed, severely impacting education in general (Blavatnik, 2020). In Latin America and the Caribbean, the temporary interruption of academic activities due to COVID19 affected 23.4 million university students and 1.4 million professors, more than $98 \%$ of students and teachers from the region (UNESCO, 2020b).

Countries, organizations, and educational institutions had to double their efforts to continue distance education and reduce the impact of this school closure, particularly among vulnerable and disadvantaged communities (UNESCO, 2020a). By resuming activities with virtual classes, and the challenges faced by HEIs in pedagogical aspects and technical infrastructure to implement the new way of teaching, universities worldwide have reported negative impacts on research issues and students' mobility (Marinoni et al., 2020).

Due to the pandemic, higher education institutions have moved into an emerging situation of distance education, which will have many impacts, some have not yet been documented or have not been perceived. There are three main reasons why this effort of pedagogical continuity may not go well: the first is the technological aspect since according to data from the International Telecommunications Union in Latin America, only 52\% of households have technological equipment and broadband connectivity, the second is the distance education coverage of higher education in 2017 only represented $15.3 \%$ of the total and covered 4.3 million students, in the absence of planning has led students to think that education is poor, and the third and last is related to teaching skills in distance education by using scarce technological resources for teaching as if they were still in the classroom (Pedró, 2020). In 2017 the Ibero-American Observatory of Science, Technology, and Society (OCTS) reported that university students studying the distance education modality represented $15.3 \%$ of the total enrollment, that is, 4.3 million students (OCTS, 2019). However, the modality was still incipient in Latin America and was contrasting among the countries due to economic and social inequalities and the existing digital divide in the region (UNESCO, 2020b).

Ibero-American counties show an upward trend as the enrollment of distance students pursuing a first degree in higher education increased by $72.9 \%$ from 2010 to 2017 and only $27.3 \%$ in face-to-face education (OCTS, 2019). Even though a large majority of the population in Mexico has access to the Internet and a mobile device; there are considerable challenges in distance education without considering that this modality represents a valuable tool to increase education coverage in its population.

In research that used the UNESCO ICT Competency Framework for Teachers 2008 intending to evaluate the management of the ICTS for the application of the class plan, a population of 922 professors of Mexican public universities whose employed sample was 432 volunteers, gave the following results: most professors use email and the Internet in an average of four times a week. The didactic use of technologies is related to the different scientific universes (hard and soft sciences). 
Professors who have ICT training possess a greater mastery of developing teaching support materials. The more proficient they are in ICT, the higher their score in an educational application, and the younger they are, the more proficient they are in ICT (Vera Noriega et al., 2014).

For this reason, the abrupt change of modality did not have the best reception by students and professors. The institutions did not design the contents as distance courses before, which requires a more significant commitment and discipline from the student. Something crucial was the disadvantages of some students due to the lack of adequate technological resources to continue with their studies successfully.

In this sense, the context of our country is not very favorable. According to the National Council for the Evaluation of Social Development Policy (CONEVAL), in 2018 , the population living in poverty in Mexico was $41.9 \%$, and $7.4 \%$ in extreme poverty; $29.3 \%$ were in conditions of vulnerability due to social deprivation, and only $21.9 \%$ of the population was not in conditions of poverty or vulnerability (CONEVAL, 2019).

According to the National Institute of Statistics and Geography (INEGI), in Mexico, there are 80.6 million Internet users aged six years or more $(70.1 \%), 44.4 \%$ have a computer, $56.4 \%$ of households have Internet access, whether by fixed or mobile connection, $95.3 \%$ connect to a smartphone, $33.2 \%$ to a laptop and $28.9 \%$ to a desktop. However, $91.5 \%$ use the Internet for entertainment, $90.7 \%$ for information, $90.6 \%$ for communication, $83.8 \%$ for education/training $83.8 \%$. The three most important groups of Internet users are 18 to 24 years old $(91.2 \%)$, the second group is 12 to 17 years old $(87.8 \%)$, and the third group is 25 to 34 years old (86.9\%) (INEGI, 2019).

In the rank called "Measuring the Information Society Report 2017" made by the International Telecommunication Union (ITU), Mexico was in 87th place of the world (ITU, 2017).

In this scenario, the considerable consequences of education in general and university have been evident. Students' and professors' challenges worldwide have been enormous (Almarzooq et al., 2020). Starting with the authorities' declared health emergency on March 21, 2020, Mexican universities experienced an unprecedented situation, a massive change from traditional "face-to-face" teaching to an online education model. The health emergency caused by COVID19 pandemic revealed the deficiencies that many of Mexico's universities had concerning virtual modalities.

Virtual education requires specific skills in both students and professors; it is essential to plan contents, activities, and the effective and efficient use of technological tools in the virtual environment in which the teaching-learning process will take place. As an immediate response to the situation, the institutions had to decide which virtual learning environment (VLE) to use, while professors have had to rethink and innovate their traditional teaching practice to adapt it to 
new circumstances in virtual mode. Some had training and experience before the pandemic, while others improvised to get ahead with the course contents.

It was imperative to anticipate integrating the ICTs into the curriculum as part of educational change and innovation. It was also important to consider that teacher's constant training is a variable that influences the incorporation of ICTs into the teaching and learning process (Rangel Baca \& Peñalosa Castro, 2013).

Given the need to continue with the January-June 2020 semester, the university authorities of the Autonomous University of Chihuahua (UACH) gave the instructions to continue with the development of the course content through the use of educational platforms and the tools to establish contact with students. Although the UACH already had extensive experience in virtual education, there is no doubt that the challenge was enormous, given the need for 100 percent of the professors to have the appropriate training to continue with their classes. As in the whole country, in this university, within a short period, more than 29,000 students and 2,935 professors (UACH, 2019) found it necessary to continue their courses at a distance, connected through the Internet, using available educational platforms and other communication resources. In the case of the University of Chihuahua, we chose Moodle because this platform is a learned-oriented (AlAjlan \& Zedan, 2008) resource. It allows the teacher to post new items such as assignments, books, files, web pages, and YouTube videos, parallel to using WebEx, Zoom, Google Classroom, Skype, or Facebook to hold video conferences with the students. It is evident that the institution, like all universities in Mexico and the world, needed to find practical and immediate technological solutions to optimize the distance learning education process at an accelerated pace. Therefore, it is unknown whether the abrupt change of modality has had a significant adverse effect on the teaching-learning process.

It is also essential to asses professors and students as well as institutional response capacity to know these actors' experiences about their performance, preferences, and difficulties they had to face during the semester. In the same way, it is interesting to evaluate the emotional effects that arose as a consequence of the days of uncertainty while all the university students were adapting to the new situation, carrying out, unexpectedly, unplanned activities. The practical implications of the knowledge that we can obtain from this study are related to the administration and professors' strategies, especially considering the students' feelings, the limited access to technological resources and connectivity problems.

The objective of this work is to understand the transition process from classroom to online classes. It is evident everyone is trying their best to cope with the challenges they faced in that context. However, a central question arises: What are the perceptions of the transition to virtual classes among the University of Chihuahua professors and students given the confinement during the pandemic caused by COVID-19? To meet the objective of this research, an inductive theoretical model is necessary, where the information from a sample of individuals allows us to explain a phenomenon and infer the behavior of the 
selected population. The survey, Likert scale, statistical analysis, and quantitative measurements are the basis to obtain answers from the selected population.

\section{Materials and methods}

Researchers conducted this cross-sectional study during the three-month timeline of April and June 2020. It is a cross-sectional design since its objective is to identify the frequency of conditions in students and professors. The researchers did not perform any intervention (interference), and the variables had only one measurement in each participating individual (Rodríguez \& Mendivelso, 2018). This work follows a quantitative method research paradigm, with an exploratory, projective and descriptive character, to understand the phenomena under study, where human beings and diversity are involved (Pereira Pérez, 2011). The authors also chose exploratory research because it approaches a little-studied topic such as virtually in times of COVID-19 and the results may generate data and elements to identify the context and subsequently conduct descriptive research that is a new topic of study (Arias, 2012). One public university was the study population: University of Chihuahua (UACH), located in Chihuahua, Mexico. This higher education institution selected the B.A. in English Language students and professors because of the accessibility of the institutional information necessary to carry out this study. Our institution does not have an ethics committee but privacy principles; we observed the subjects' confidentiality, anonymity, and protection.

Drawing from data available through the Strategic System of Academic Management (SEGA), we identified 230 students of the Bachelor in English Language Program (undergraduate students) as the institution's population of interest. The researchers used Cochran's formula (see details below) to determine the sample size (145 students), with a confidence interval of $95 \%$ and a $5 \%$ margin error; even that 152 had participated, it was a non-probability, for convenience sampling since the participation was voluntary (Mcmillan \& Schumacher, 2005).

$$
n=\frac{N * Z^{2} * p * q}{(N-1) * e^{2}+Z^{2} * p * q}
$$

Where:

$\mathrm{n}=$ sample size

$\mathrm{N}=$ total number of elements that make up the population.

$Z=$ reliability coefficient score.

$\mathrm{e}=$ margin of error

$p=$ proportion of elements exhibiting a certain characteristic

$q=$ proportion of elements that do not present the characteristic under research.

A total of 152 students answered an instrument (Appendix 1). It contained 28 statements they valued through a five-point Likert Scale that allowed students to express how much they agreed or disagreed with the statements divided into 
three categories: advantages, disadvantages, and modality preference of virtual vs classroom classes, plus four variables to stratify the results.

After selecting the sample of students, we conducted a semi-structured survey with them, and we used another instrument for the professors and grouped the questions in six sections (training, teaching-learning process, institutional aspects, infrastructure, limitations, virtual modality) in a 51-item mixed survey questionnaire made up of Likert scale questions, yes-no questions, and a multiplechoice question (Appendix 2). These instruments enabled the collection of quantitative data that emerged from participants' practices and experiences with the issues related to COVID-19.

The data were collected using a Google Forms survey sent to the participants via email and WhatsApp and analyzed with the statistical software IBM ${ }^{\circledR}$ SPSS version 20 through descriptive statistical techniques such as frequency distributions, central tendency measures and dispersion measures.

\section{Results and Discussion}

a) Students' survey.

Out of the 152 Bachelor in the English Language students who participated in the survey, 120 (79\%) were women, and 32 (21\%) were men; 86\% (131) of the students who answered the survey were in the city of Chihuahua, Mexico, 19 (13\%) were in other towns within the State of Chihuahua, while two (1.3\%) were in the State of Sonora, México.

According to the data shown in Table 1, we may think that students could maintain good communication with their professors and classmates during the semester in confinement since a large proportion answered to agree with this statement (66.4 and $65.1 \%$, respectively). However, the remaining $34 \%$ who could not affirm the same draw attention, especially in a modality where constant communication is essential to carry out the contents successfully (Table 1).

Table 1. Student's perceptions of the advantages of taking virtual classes.

\begin{tabular}{|c|c|c|c|c|c|c|c|c|c|c|c|}
\hline \multirow[t]{2}{*}{ Question } & \multicolumn{2}{|c|}{$\begin{array}{l}\text { Strongly } \\
\text { agree }\end{array}$} & \multicolumn{2}{|c|}{$\begin{array}{c}\text { Somewhat } \\
\text { agree }\end{array}$} & \multicolumn{2}{|c|}{$\begin{array}{l}\text { Neither agree } \\
\text { nor disagree }\end{array}$} & \multicolumn{2}{|c|}{$\begin{array}{c}\text { Somewhat } \\
\text { disagree }\end{array}$} & \multicolumn{2}{|c|}{$\begin{array}{l}\text { Strongly } \\
\text { disagree }\end{array}$} & \multirow[t]{2}{*}{ SD } \\
\hline & $f$ & $\%$ & $f$ & $\%$ & $\mathrm{f}$ & $\%$ & $\mathrm{f}$ & $\%$ & $F$ & $\%$ & \\
\hline $\begin{array}{l}\text { My level of self-confidence has } \\
\text { increased from virtual classes }\end{array}$ & 6 & 3.9 & 27 & 17.8 & 58 & 38.2 & 36 & 23.7 & 25 & 16.4 & 18.9 \\
\hline $\begin{array}{l}\text { I maintain good communication } \\
\text { with my teachers in the virtual } \\
\text { modality }\end{array}$ & 38 & 25.0 & 63 & 41.4 & 23 & 15.1 & 17 & 11.2 & 11 & 7.2 & 20.8 \\
\hline $\begin{array}{l}\text { I maintain good communication } \\
\text { with my classmates in the } \\
\text { virtual modality }\end{array}$ & 41 & 27.0 & 58 & 38.2 & 24 & 15.8 & 18 & 11.8 & 11 & 7.2 & 19.0 \\
\hline $\begin{array}{l}\text { My ability to analyze } \\
\text { information has improved from } \\
\text { virtual classes }\end{array}$ & 10 & 6.6 & 35 & 23.0 & 53 & 34.9 & 33 & 21.7 & 21 & 13.8 & 16.1 \\
\hline $\begin{array}{l}\text { I manage my time efficiently in } \\
\text { the virtual modality }\end{array}$ & 22 & 14.5 & 28 & 18.4 & 39 & 25.7 & 29 & 19.1 & 34 & 22.4 & 6.4 \\
\hline $\begin{array}{l}\text { Online exams offer me more } \\
\text { advantages than the exams I } \\
\text { take in the classroom }\end{array}$ & 26 & 17.1 & 43 & 28.3 & 37 & 24.3 & 19 & 12.5 & 27 & 17.8 & 9.5 \\
\hline
\end{tabular}




\begin{tabular}{|l|c|c|c|c|c|c|c|c|c|c|c|}
\hline $\begin{array}{l}\text { The virtual learning process at } \\
\text { UACH is supported by state-of- } \\
\text { the-art platforms }\end{array}$ & 11 & 7.2 & 35 & 23.0 & 63 & 41.4 & 19 & 12.5 & 24 & 15.8 & 20.2 \\
\hline $\begin{array}{l}\text { Online classes allow me to relate } \\
\text { theory and practice }\end{array}$ & 8 & 5.3 & 34 & 22.4 & 45 & 29.6 & 38 & 25.0 & 27 & 17.8 & 14.1 \\
\hline $\begin{array}{l}\text { I have had access to the Internet } \\
\text { since classes started in the } \\
\text { virtual modality }\end{array}$ & 95 & 62.5 & 26 & 17.1 & 13 & 8.6 & 9 & 5.9 & 9 & 5.9 & 36.8 \\
\hline $\begin{array}{l}\text { I have had access to a computer } \\
\text { since classes started in the } \\
\text { virtual modality }\end{array}$ & 101 & 66.4 & 28 & 18.4 & 9 & 5.9 & 7 & 4.6 & 7 & 4.6 & 40.4 \\
\hline $\begin{array}{l}\text { I have more free time for non- } \\
\text { school related activities since I } \\
\text { began taking virtual classes }\end{array}$ & 39 & 25.7 & 26 & 17.1 & 35 & 23.0 & 20 & 13.2 & 32 & 21.1 & 7.5 \\
\hline $\begin{array}{l}\text { My expenses were reduced } \\
\text { when I started taking virtual } \\
\text { classes }\end{array}$ & 61 & 40.1 & 49 & 32.2 & 28 & 18.4 & 6 & 3.9 & 8 & 5.3 & 24.4 \\
\hline $\begin{array}{l}\text { My teachers are using better teaching } \\
\text { strategies in virtual education } \\
\text { compared to the strategies they use } \\
\text { during face-to-faceclasses }\end{array}$ & 11 & 7.2 & 21 & 13.8 & 45 & 29.6 & 44 & 28.9 & 31 & 20.4 & 14.7 \\
\hline Total/Mean & $\mathbf{4 6 9}$ & $\mathbf{2 3 . 7}$ & $\mathbf{4 7 3}$ & $\mathbf{2 3 . 9}$ & $\mathbf{4 7 2}$ & $\mathbf{2 3 . 8}$ & $\mathbf{2 9 5}$ & $\mathbf{1 4 . 9}$ & $\mathbf{2 6 7}$ & $\mathbf{1 3 . 5}$ & $\mathbf{1 9 . 2}$ \\
\hline
\end{tabular}

About the students' perception of the disadvantages of this modality (Table 2), some of the relevant responses of the students relate to experiencing anxiety with virtual classes $(69.1 \%)$ and feeling isolated $(62.5 \%)$ during the contingency. Universities should pay attention to this situation since it could affect university students' emotional state (Dill et al., 2020), translating into low achievement and dropout. These results are far above the study of González-Jaimes et al. (2020), where $32 \%$ of 644 university students surveyed from seven states of the Mexican Republic expressed the presence of symptoms of stress, and $40 \%$ anxiety. This stress is explainable because of the difficulties they experienced through interactions with professors $(86.1 \%)$ and classmates $(67.1 \%)$, as well as the difficulty in organizing their online activities (62.5\%) (Table 2).

Table 2. Student's perceptions of the disadvantages of taking virtual classes.

\begin{tabular}{|c|c|c|c|c|c|c|c|c|c|c|c|}
\hline \multirow{2}{*}{ Question } & \multicolumn{2}{|c|}{$\begin{array}{l}\text { Strongly } \\
\text { agree }\end{array}$} & \multicolumn{2}{|c|}{$\begin{array}{l}\text { Somewhat } \\
\text { agree }\end{array}$} & \multicolumn{2}{|c|}{$\begin{array}{l}\text { Neither agree } \\
\text { nor disagree }\end{array}$} & \multicolumn{2}{|c|}{$\begin{array}{c}\text { Somewhat } \\
\text { disagree }\end{array}$} & \multicolumn{2}{|c|}{$\begin{array}{l}\text { Strongly } \\
\text { disagree }\end{array}$} & \multirow{2}{*}{ SD } \\
\hline & $\mathrm{f}$ & $\%$ & $\mathrm{f}$ & $\%$ & $\mathrm{f}$ & $\%$ & $\mathrm{f}$ & $\%$ & $\mathrm{f}$ & $\%$ & \\
\hline $\begin{array}{l}\text { I don't understand the } \\
\text { instructions in my virtual } \\
\text { classes }\end{array}$ & 21 & 13.8 & 60 & 39.5 & 35 & 23.0 & 22 & 14.5 & 14 & 9.2 & 18.2 \\
\hline $\begin{array}{l}\text { I experience anxiety taking } \\
\text { virtual classes }\end{array}$ & 54 & 35.5 & 51 & 33.6 & 15 & 9.9 & 13 & 8.6 & 19 & 12.5 & 20.3 \\
\hline I feel isolated & 53 & 34.9 & 42 & 27.6 & 23 & 15.1 & 10 & 6.6 & 24 & 15.8 & 17.0 \\
\hline $\begin{array}{l}\text { The interaction with the } \\
\text { teacher is affected during the } \\
\text { class due to technical } \\
\text { problems }\end{array}$ & 75 & 49.3 & 56 & 36.8 & 12 & 7.9 & 8 & 5.3 & 1 & 0.7 & 33.0 \\
\hline $\begin{array}{l}\text { The interaction with my classmates } \\
\text { is complicated sinceit does not } \\
\text { happen spontaneously due to turn- } \\
\text { taking on the microphone }\end{array}$ & 63 & 41.4 & 39 & 25.7 & 27 & 17.8 & 13 & 8.6 & 10 & 6.6 & 21.6 \\
\hline
\end{tabular}




\begin{tabular}{|l|c|c|c|c|c|c|c|c|c|c|c|}
\hline $\begin{array}{l}\text { I have difficulty organizing } \\
\text { online homework }\end{array}$ & 55 & 36.2 & 40 & 26.3 & 22 & 14.5 & 12 & 7.9 & 23 & 15.1 & 17.0 \\
\hline $\begin{array}{l}\text { I don't know how many } \\
\text { hours I should dedicate to the } \\
\text { virtual program }\end{array}$ & 55 & 36.2 & 37 & 24.3 & 36 & 23.7 & 9 & 5.9 & 15 & 9.9 & 18.5 \\
\hline $\begin{array}{l}\text { It is difficult for me to access } \\
\text { the Internet }\end{array}$ & 11 & 7.2 & 22 & 14.5 & 30 & 19.7 & 25 & 16.4 & 64 & 42.1 & 20.0 \\
\hline $\begin{array}{l}\text { I have had difficulties } \\
\text { accessing the contents of the } \\
\text { UACH platform }\end{array}$ & 20 & 13.2 & 36 & 23.7 & 31 & 20.4 & 37 & 24.3 & 28 & 18.4 & 6.9 \\
\hline Total/Mean & $\mathbf{4 0 7}$ & $\mathbf{3 0}$ & $\mathbf{3 8 3}$ & $\mathbf{2 8}$ & $\mathbf{2 3 1}$ & $\mathbf{1 7}$ & $\mathbf{1 4 9}$ & $\mathbf{1 1}$ & $\mathbf{1 9 8}$ & $\mathbf{1 4}$ & $\mathbf{1 9 . 2}$ \\
\hline
\end{tabular}

We consulted the students on what modality they prefer. Students prefer face-toface classes over virtual classes. The vast majority (93\%) considered that interaction with the teacher is better face-to-face than virtually, $85 \%$ think that they learn better in classroom classes, and $78 \%$ disagree with the statement that they would like all their classes to be virtual (Figure 2). Undoubtedly, these results reflect what Pedró (2020) reports on students' attitudes towards distance programs, who seek to receive online classes as if they were face-to-face, only adding the technological aspect.

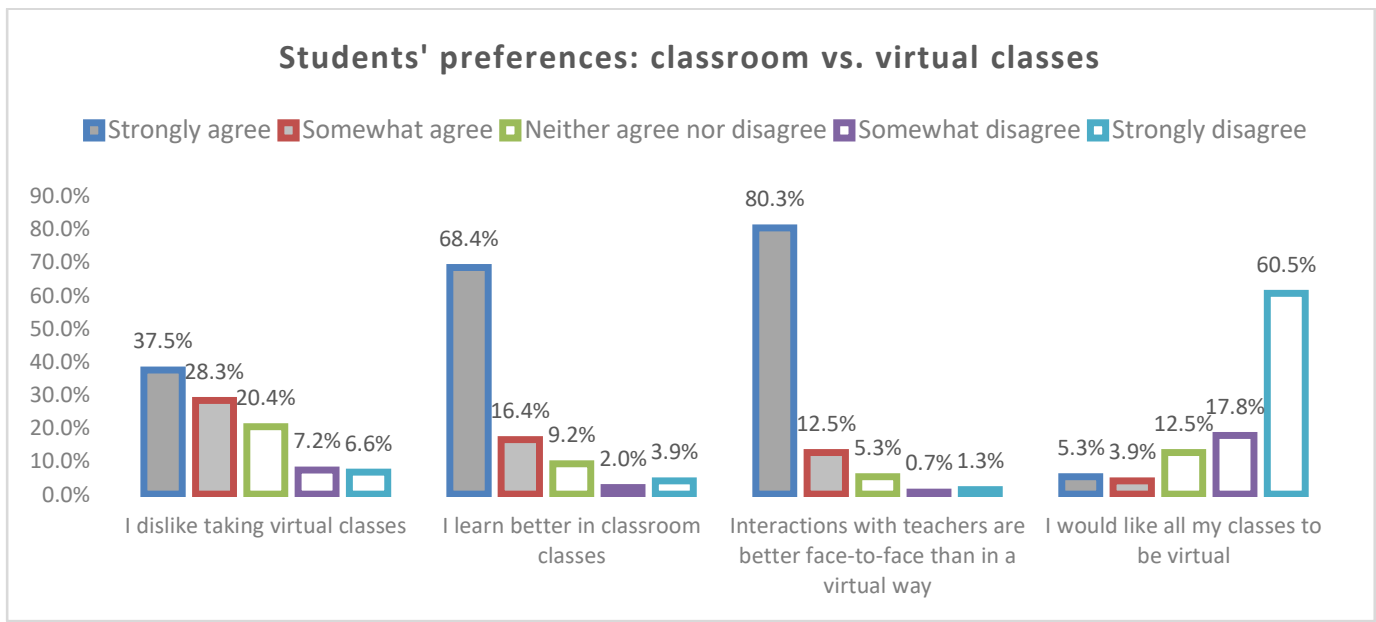

Figure 2. Students' preferences: classroom vs virtual classes.

Students living in different locations in the State capital had much more trouble accessing the Internet for their classes. This result may also be a reflection of the vulnerable situation in which many Mexicans live (CONEVAL, 2019), the lack of connectivity and limited technological resources (INEGI, 2019), and information literacy still deficient in a significant proportion of the population in Mexico (ITU, 2017).

Translating the Likert scale to numerical rating, where 1 means Strongly disagree, 2 Somewhat disagree, 3 Neither agree nor disagree, 4 Somewhat agree and, 5 Strongly agree, the mean to the question "I have had access to the Internet since classes started in the virtual modality" results with an $\bar{x}=4.35$ for the students living in the city of Chihuahua and $\bar{x}=3.57$ for the students of other locations.

The difference in means was significant with the t-test for independent samples $(p<0.05)$. Other questions that showed statistically significant differences $(p<$ 
0.05) for these two groups of students mentioned were: "Online classes offer more advantages compared to classroom learning". Students from other locations (usually rural) feel that they have more advantages with this type of online class modality; however, these same students reported having more difficulty accessing the Internet $(\bar{x}=3.05)$ vs. the students of the state capital $(\bar{x}=2.16)$ (See Table 3).

Table 3. Comparison of significant differences in means of student location.

\begin{tabular}{|l|c|c|c|c|c|c|}
\hline \multirow{2}{*}{ Question } & \multicolumn{3}{c|}{ Chihuahua } & \multicolumn{2}{c|}{ Other locations of the State } \\
\cline { 2 - 7 } & Mean & $\mathbf{N}$ & $\begin{array}{c}\text { Standard } \\
\text { deviation }\end{array}$ & Mean & N & $\begin{array}{c}\text { Standard } \\
\text { deviation }\end{array}$ \\
\hline $\begin{array}{l}\text { The interaction with my classmates } \\
\text { is complicated since it does not } \\
\text { happen spontaneously due to turn- } \\
\text { taking on the microphone }\end{array}$ & 3.75 & 131 & 1.26 & 4.62 & 21 & 0.67 \\
\hline $\begin{array}{l}\text { Online classes offer more } \\
\text { advantages compared to classroom } \\
\text { learning }\end{array}$ & 2.29 & 131 & 1.21 & 3.10 & 21 & 1.04 \\
\hline $\begin{array}{l}\text { I have difficulty organizing online } \\
\text { homework }\end{array}$ & 3.51 & 131 & 1.48 & 4.19 & 21 & 0.93 \\
\hline $\begin{array}{l}\text { It is difficult for me to access the } \\
\text { Internet }\end{array}$ & 2.16 & 131 & 1.27 & 3.05 & 21 & 1.50 \\
\hline
\end{tabular}

By grouping the variables that corresponded to the Advantages and Disadvantages of virtual education, there is a significant moderate positive correlation $(p<0.05)$ between the students who said they prefer face-to-face classes and the Disadvantages category, with a Pearson correlation coefficient of 0.366 .

b) Professors' survey.

One hundred percent of the professors of the Bachelor of English Language program answered the survey. Of the 26 professors, 19 (73\%) are women, with an average age of 48.3 years, and $7(17 \%)$ are men, with an average of 43.9 years. Of the 26 professors surveyed, $16(62 \%)$ are full-tenured, and $10(38 \%)$ are nontenured professors; two $(7.7 \%)$ have a bachelor's degree, $13(50 \%)$ have a master's degree, and $11(42.3 \%)$ have a doctorate. The majority of professors $(73 \%)$ teach only in undergraduate programs, while $27 \%$, in addition to undergraduate programs, attend masters and doctorate courses. Regarding seniority in general, the professors have 15.1 years of teaching experience, the average seniority of female professors is 14.8 years, and 16.0 years of the male professors.

Due to the pandemic, the contingency has been an unexpected situation in all areas of our lives. In the academic aspect, in higher education, professors suddenly went from classrooms to remote sessions supported by technology and computer tools to teach classes. Suddenly, we faced a complicated situation that required professors to have training in digital and communication tools. For example, many in this group of professors trained previously, but some did not prepare. This lack of training can be understood because, before this situation, virtual education in this institution was only an alternative; now, it has become an obligation. Regarding the experience using virtual learning platforms, 19 (73\%) 
of the professors indicated that they had previously used these tools, while 7 $(27 \%)$ stated that they had no previous experience. Fourteen of them $(53.8 \%)$ took training previously, 9 (34.6\%) got training courses during the contingency, and 3 $(11.5 \%)$ of them mentioned that they had not received any training yet. Three professors $(11.5 \%)$ considered that they had a low level of training to teach in virtual environments; 17 (65.4\%) answered that they had an intermediate level, and $6(23.1 \%)$ stated that they had a high level of training in these tools. Regarding the institutional support received, this study coincides with that of Sánchez et al. (2020), who surveyed 788 professors from UNAM, where $60.5 \%$ acknowledged having had institutional support to face the challenges of the pandemic.

In the present study, regarding the university's training, 50\% affirmed that this training gave them sufficient elements to teach in virtual environments, $19.2 \%$ considered it did not give them sufficient elements to teach, and 30.8\% answered that it partially did. As mentioned before, we agree with other researchers that, during the contingency, university-level professors' proficiency of digital skills takes particular relevance to move forward with the course content (MartínezGarcés \& Garcés-Fuenmayor, 2020). About the tools that the professors used to teach during the semester, $17(65.4 \%)$ used Virtual Classrooms, 21 (80.8\%) used social networks, $25(96.2 \%)$ also supported themselves with video conferences, and $17(65.4 \%)$ used email additionally. Most of the professors $(81.8 \%)$ used the Moodle platform for their courses, while $18.2 \%$ preferred Google Classroom, and only one of the professors used Schoology during this contingency.

Although the university was flexible regarding the professors' tools, Moodle is the platform that the institution used for the courses this semester. These results are consistent with those of Sánchez et al. (2020), where most professors trusted the institutional platform to carry out their courses. Regarding the tools for video conferences, the professors combined the virtual platforms; most of the professors $(96.2 \%)$ used Zoom to teach their classes, $57.7 \%$ used WebEx, which is the tool that the institution provides to professors, $53.8 \%$ connected via Google Meet, while $23 \%$ used other tools, like Skype, WhatsApp, and Facebook to establish communication with the students. Although the UNAM professors used almost the same resources as those of our institution, at the UACH, Zoom's use was preferred for distance sessions, while people at the UNAM preferred Google Hangouts (Sánchez et al., 2020). It should be noted that the UACH reported frequent failures when using the WebEx tool, which was the recommended platform by the institution to carry out the sessions.

Table 4. Students' overall performance during the contingency.

\begin{tabular}{|c|c|c|c|c|c|c|c|c|c|c|c|}
\hline \multirow{2}{*}{ Question } & \multicolumn{2}{|c|}{ Excellent } & \multicolumn{2}{|c|}{ Good } & \multicolumn{2}{|c|}{ Regular } & \multicolumn{2}{|c|}{ Poor } & \multicolumn{2}{|c|}{$\begin{array}{l}\text { Seriously } \\
\text { deficient }\end{array}$} & \multirow{2}{*}{ SD } \\
\hline & $\mathbf{f}$ & $\%$ & $\mathbf{f}$ & $\%$ & $\mathbf{f}$ & $\%$ & f & $\%$ & $f$ & $\%$ & \\
\hline $\begin{array}{l}\text { Motivation during class } \\
\text { activities }\end{array}$ & 3 & 11.5 & 12 & 46.2 & 10 & 38.5 & 1 & 3.8 & 0 & 0.0 & 5.4 \\
\hline Class attendance & 5 & 19.2 & 13 & 50.0 & 6 & 23.1 & 2 & 7.7 & 0 & 0.0 & 5.0 \\
\hline Task and work fulfillment & 8 & 30.8 & 14 & 53.8 & 4 & 15.4 & 0 & 0.0 & 0 & 0.0 & 5.9 \\
\hline $\begin{array}{l}\text { Extra time and attention for } \\
\text { reviews and study }\end{array}$ & 6 & 23.1 & 13 & 50.0 & 5 & 19.2 & 2 & 7.7 & 0 & 0.0 & 5.0 \\
\hline
\end{tabular}




\begin{tabular}{|l|c|c|c|c|c|c|c|c|c|c|c|}
\hline $\begin{array}{l}\text { Browsing of materials and } \\
\text { bibliography }\end{array}$ & 3 & 11.5 & 14 & 53.8 & 7 & 26.9 & 1 & 3.8 & 1 & 3.8 & 5.5 \\
\hline Use of information technologies & 7 & 26.9 & 15 & 57.7 & 3 & 11.5 & 1 & 3.8 & 0 & 0.0 & 6.1 \\
\hline Optimal use of class time & 3 & 11.5 & 18 & 69.2 & 4 & 15.4 & 1 & 3.8 & 0 & 0.0 & 7.3 \\
\hline Total/Mean & $\mathbf{3 5}$ & $\mathbf{1 9}$ & $\mathbf{9 9}$ & $\mathbf{5 4}$ & $\mathbf{3 9}$ & $\mathbf{2 1}$ & $\mathbf{8}$ & $\mathbf{4 . 4}$ & $\mathbf{1}$ & $\mathbf{0 . 5}$ & $\mathbf{5 . 7}$ \\
\hline
\end{tabular}

In general, the professors stated that the performance of the students during the contingency was good. It stands out that $84.6 \%$ think that students have an excellent or a good level using information technologies. The same percentage of professors consider performance in terms of fulfilling tasks and works between good and excellent. The results are consistent with an experimental study carried out with 458 university students in Spain, where they found that the students improved their performance and ability to develop tasks during confinement (Gonzalez et al., 2020). In that study, the best performance related to the assessment processes and the new learning methodology; in the present study, the professors rated the students' good level when using information technologies (Table 4). The aspect with the highest negative evaluation turned out to be that of motivation during class activities; here, $42.3 \%$ considered the performance of the students to be between fair and poor (Table 4), which is understandable, and it coincides with the argument of Dill et al. (2020) since the same students reported having experienced negative emotions such as feeling isolated and experiencing anxiety during the confinement (Table 2).

Table 5. Teaching-Learning Process.

\begin{tabular}{|c|c|c|c|c|c|c|c|c|c|c|c|}
\hline \multirow{2}{*}{ Question } & \multicolumn{2}{|c|}{$\begin{array}{l}\text { Strongly } \\
\text { agree }\end{array}$} & \multicolumn{2}{|c|}{$\begin{array}{c}\text { Somewhat } \\
\text { agree }\end{array}$} & \multicolumn{2}{|c|}{$\begin{array}{l}\text { Neither agree } \\
\text { nor disagree }\end{array}$} & \multicolumn{2}{|c|}{$\begin{array}{c}\text { Somewhat } \\
\text { disagree }\end{array}$} & \multicolumn{2}{|c|}{$\begin{array}{l}\text { Strongly } \\
\text { disagree }\end{array}$} & \multirow[t]{2}{*}{ SD } \\
\hline & f & $\%$ & f & $\%$ & f & $\%$ & f & $\%$ & $\mathbf{f}$ & $\%$ & \\
\hline $\begin{array}{l}\text { The interaction with students during } \\
\text { the semester as appropriate }\end{array}$ & 8 & 30.8 & 16 & 61.5 & 1 & 3.8 & 1 & 3.8 & 0 & 0.0 & 6.8 \\
\hline $\begin{array}{l}\text { I had to develop new teaching } \\
\text { materials for my class }\end{array}$ & 14 & 53.8 & 10 & 38.5 & 1 & 3.8 & 1 & 3.8 & 0 & 0.0 & 6.4 \\
\hline $\begin{array}{l}\text { I had to locate and adapt teaching } \\
\text { materials from other authors }\end{array}$ & 9 & 34.6 & 9 & 34.6 & 5 & 19.2 & 1 & 3.8 & 2 & 7.7 & 3.8 \\
\hline $\begin{array}{l}\text { I followed to the letter the program } \\
\text { of the subjects taught }\end{array}$ & 9 & 34.6 & 15 & 57.7 & 0 & 0.0 & 2 & 7.7 & 0 & 0.0 & 6.6 \\
\hline $\begin{array}{l}\text { I was able to cover the contents of } \\
\text { the subjects taught entirely }\end{array}$ & 9 & 34.6 & 13 & 50.0 & 0 & 0.0 & 4 & 15.4 & 0 & 0.0 & 5.7 \\
\hline $\begin{array}{l}\text { The students' academic performance } \\
\text { during this semester was lower in } \\
\text { comparison to last semester }\end{array}$ & 6 & 23.1 & 12 & 46.2 & 4 & 15.4 & 1 & 3.8 & 3 & 11.5 & 4.2 \\
\hline Total/Mean & 55 & 35.3 & 75 & 48.1 & 11 & 7.03 & 10 & 6.38 & 5 & 3.2 & 5.6 \\
\hline
\end{tabular}

Regarding the teaching-learning process, $92.3 \%$ of the professors had to develop new materials for their classes, and $69.2 \%$ said they needed to adapt teaching materials from other authors. Even though the situation changed in the middle of the semester, $92.3 \%$ of the professors affirmed that they followed the program to the letter, while $84.6 \%$ said they had completely covered the subjects' contents. Even though these results were encouraging for the teaching-learning process, it is striking that a large proportion of professors (69.3\%) think that the students' performance was lower compared to the last semester, where students only had a 
face-to-face modality. We may think that it is a contradictory finding, but it is not, since there was a previous discussion about the perception of the student's performance, which professors rated as good, but we understand that professors thought at the same time that it was not as good as in former periods, where they only had face-to-face classes. An objective way to measure performance would be comparing grades between semesters, as Gonzalez et al. (2020) did. However, this objective was outside the scope of this research.

Regarding the experience in virtual mode, the professors are positive, since a large proportion of them $(76.9 \%)$ consider that the virtual classes have helped them to improve their teaching practice; $92.3 \%$ stated that the communication with the students was easy and the same proportion $(92.3 \%)$, said they feel prepared to carry out another semester virtually if necessary (Figure 3). In general, professors are optimistic about taking on the challenge of virtual classes, as Prokopenko \& Berezhna (2020) reported, whose professors agreed that this situation also motivated them to improve their creativity and skills for a distance teachinglearning process. Despite this, only $15.4 \%$ prefer virtual classes over classroom classes, and half of them do not agree that students learn better in the virtual model, which is consistent with the vision of students who do not like virtual classes because they consider that learning and interaction are better in face-toface courses (Figures 2 and 3).

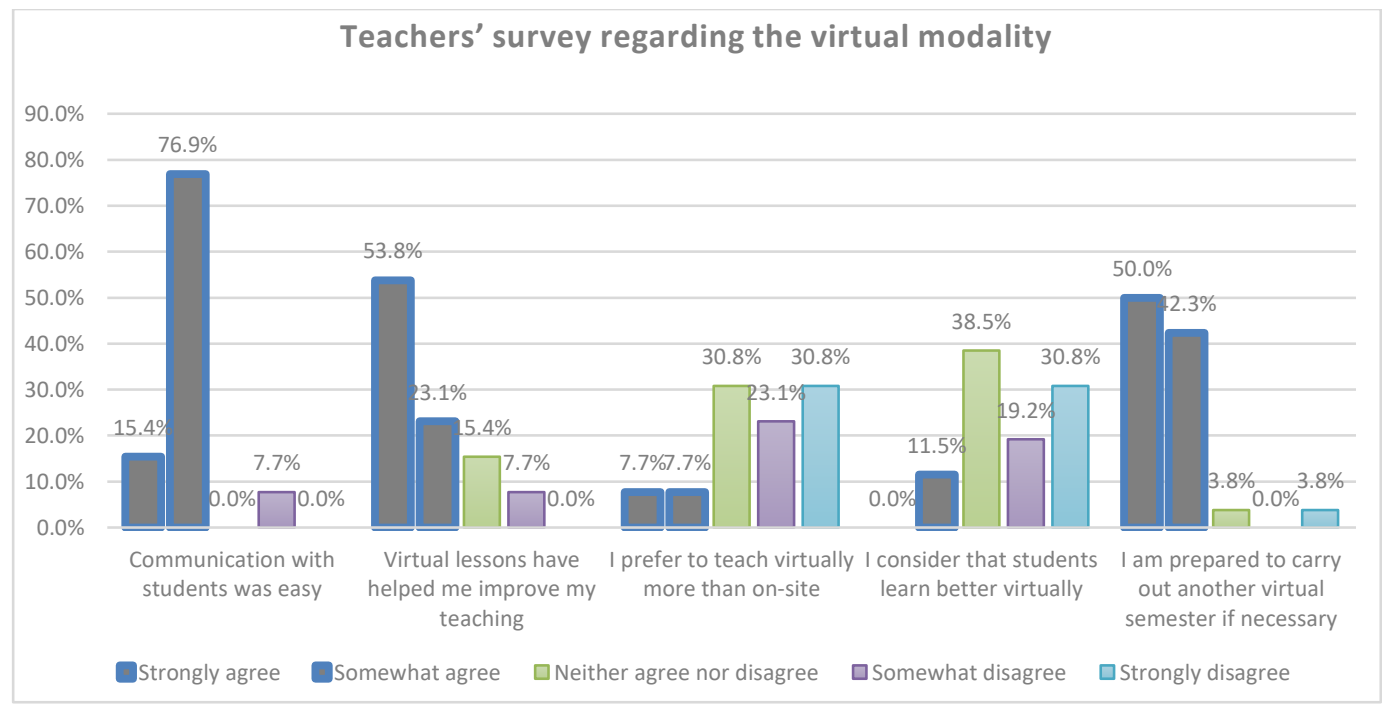

Figure 3. Professors' survey regarding the virtual modality.

When analyzing the institutional aspects, $80.8 \%$ of the professors answered that they received support from the institution to communicate with their students; 92.3\% received timely communication from the academic area, and 84.6\% answered that the administrative area's communication was equally timely. While $84.6 \%$ considered that the institution's contingency face strategies were appropriate, only $38.5 \%$ think that the university had a contingency plan previously. At a global level, although the COVID-19 pandemic had an immediate impact on the academic activities of universities, a study with 406 universities from 109 countries reveals that $91 \%$ considered that they were prepared with the 
necessary infrastructure to maintain good communication with their students and professors (Marinoni et al., 2020).

Although the challenge of achieving effective communication with students was great initially, this variable did not represent a significant problem for this university community since the $\mathrm{UACH}$ has come a long way in virtual teaching and experiences with blended learning schemes. Finally, in this university, 80.8\% of the professors think that the institution is prepared to take another virtual semester if necessary.

Table 6. Institutional aspects.

\begin{tabular}{|c|c|c|c|c|c|c|c|c|c|c|c|}
\hline \multirow{2}{*}{ Question } & \multicolumn{2}{|c|}{$\begin{array}{l}\text { Strongly } \\
\text { agree }\end{array}$} & \multicolumn{2}{|c|}{$\begin{array}{l}\text { Somewhat } \\
\text { agree }\end{array}$} & \multicolumn{2}{|c|}{$\begin{array}{c}\text { Neither agree } \\
\text { nor disagree }\end{array}$} & \multicolumn{2}{|c|}{$\begin{array}{c}\text { Somewhat } \\
\text { disagree }\end{array}$} & \multicolumn{2}{|c|}{$\begin{array}{l}\text { Strongly } \\
\text { disagree }\end{array}$} & \multirow[t]{2}{*}{ SD } \\
\hline & f & $\%$ & f & $\%$ & f & $\%$ & f & $\%$ & f & $\%$ & \\
\hline $\begin{array}{l}\text { I received the institution's } \\
\text { support to communicate with } \\
\text { my students }\end{array}$ & 12 & 46.2 & 9 & 34.6 & 3 & 11.5 & 1 & 3.8 & 1 & 3.8 & 5.0 \\
\hline $\begin{array}{l}\text { I received timely } \\
\text { communication from the } \\
\text { institution's academic area }\end{array}$ & 14 & 53.8 & 10 & 38.5 & 1 & 3.8 & 0 & 0.0 & 1 & 3.8 & 6.4 \\
\hline $\begin{array}{l}\text { I received timely } \\
\text { communication from the } \\
\text { institution's administrative area }\end{array}$ & 11 & 42.3 & 11 & 42.3 & 1 & 3.8 & 2 & 7.7 & 1 & 3.8 & 5.3 \\
\hline $\begin{array}{l}\text { I think next semester's } \\
\text { enrollment will be lower due to } \\
\text { the circumstances }\end{array}$ & 7 & 26.9 & 11 & 42.3 & 6 & 23.1 & 2 & 7.7 & 0 & 0.0 & 4.3 \\
\hline $\begin{array}{l}\text { The institution's strategies } \\
\text { implemented in response to the } \\
\text { contingency were appropriate }\end{array}$ & 9 & 34.6 & 13 & 50 & 2 & 7.7 & 1 & 3.8 & 1 & 3.8 & 5.5 \\
\hline $\begin{array}{l}\text { I believe the institution already } \\
\text { had a formal contingency plan }\end{array}$ & 4 & 15.4 & 6 & 23.1 & 6 & 23.1 & 2 & 7.7 & 8 & 30.8 & 2.3 \\
\hline $\begin{array}{l}\text { The institution is prepared to } \\
\text { carry out another virtual } \\
\text { semester if necessary }\end{array}$ & 11 & 42.3 & 10 & 38.5 & 4 & 15.4 & 0 & 0.0 & 1 & 3.8 & 5.1 \\
\hline Total/Mean & 68 & 37.4 & 70 & 38.5 & 23 & 12.6 & 8 & 4.39 & 13 & 7.11 & 4.8 \\
\hline
\end{tabular}

\section{Conclusions}

We can conclude that most of B.A. in the English Language students' perceptions are related to the disadvantages in virtual classes, especially on the problems of accessing the Internet, difficulties interacting with professors and classmates, and not understanding clearly all the assignment instructions. During this experience, the professors used Moodle as an institutional platform. Regarding communication tools, the vast majority of professors relied on Zoom to conduct conferences with their students, and many of them combined social media to maintain contact. Despite the suddenness of the situation, we can affirm that the transition from face-to-face teaching to the virtual modality was successful, professors had the institutional support in technological resources, training, and communication to conduct the courses, and they had the opportunity to conclude the topics of their programs. However, a large proportion thinks that the performance of the students was lower than in face-to-face modality. Professors base this idea on students not using class time optimally, less participation took 
place, and they were not achieving excellent task and work fulfillment. The professors feel confident to face a new semester in virtual modality if necessary. In general, professors agreed that this situation also motivated them to improve their creativity and skills for a distance teaching-learning process. Even so, the perception of the students concerning this modality is noteworthy, since the majority affirmed that they prefer face-to-face classes to the virtual modality; this is possibly a reflection of the difficulties that students experienced when interacting with professors and classmates, as well as the difficulty in organizing their online activities and connectivity problems. The recommendations derived from this research are in three levels: professors, the education system, and the government. Professors should consider their students' context and limitations to make adjustments to their programs to successfully orient education towards critical thinking. The education system must constantly train professors by offering free online courses and lectures from experts in educational platforms and technological tools to enhance their skills. The government must support the education system by issuing laws to formalize virtual education, giving schools the necessary tools and resources to meet their needs.

This research reflects upon experiences of professors and students during the pandemic and the perception of its advantages and disadvantages; however, the limit is the resistance to migrate to online modality, coupled with the fact that sometimes there is a disconnection between the teacher and the educational authorities who often belong to the administrative area and face this challenge from another angle. The experiences from the pandemic of 2020 will lead to the development of new platforms and regulations that will allow the education system to be ready for the challenges to come.

\section{References}

Al-Ajlan, A., \& Zedan, H. (2008). Why Moodle. Proceedings of the 2008 12th IEEE International Workshop on Future Trends of Distributed Computing Systems, 58-64. https://doi.org/10.1109/FTDCS.2008.22

Almarzooq, Z., Lopes, M., \& Kochar, A. (2020). Virtual Learning During the COVID-19 Pandemic. Journal of the American College of Cardiology, 75(20), 2635-2638. https:// doi.org/10.1016/j.jacc.2020.04.015

Arias, F. G. (2012). El proyecto de Investigación [The research project] (6 Ed.). Editorial Episteme.

Blavatnik. (2020). OXFORD COVID-19 Government Response Tracker(OxCGRT). https:// data.humdata.org/ dataset/oxford-covid-19-government-responsetracker

Cabrero, J., \& Barroso, J. (2015). Nuevos retos en tecnología educativa [New challenges in educational technology] (1st ed.). Editorial Síntesis.

Casablancas, S. (2017). No es malo perder el rumbo: reconfiguraciones del rol docente en el contexto digital [It is not bad to lose the way: recofigurations of the teaching role in the digital context ]. En Educar en la era digital (pp.17-33). Editorial Pandora, S.A. de C.V. http://www.pent.org.ar/extras/micrositios/libroeducar/educar_en_la_era_digital.pdf

CONEVAL. (2019). Medición de pobreza 2008-2018, Estados Unidos Mexicanos[Poverty Measurement 2008-2018, United Mexican States]. https://www.coneval.org.mx/Medicion/PublishingImages/Pobreza_2018/Seri 
e_2008-2018.jpg

Dill, E., Fischer, K., McMurtrie, B., \& Beckie, S. (2020). As Coronavirus Spreads, Is the First Step. What's Next? The Chronicle of Higher Education, 1, 5-7.

García Contador, Y., \& Gutiérrez Esteban, P. (2020). El rol docente en la sociedad digital. [The teacher's role in the digital era]. Digital Education, 38, 1-22. https://www.redalyc.org/pdf/274/27447325008.pdf

González-Jaimes, N. L., Tejeda-Alcántara, A. A., Espinosa-Méndez, C. M., \& OntiverosHernández, Z. O. (2020). Impacto psicológico en estudiantes universitarios mexicanos por confinamiento durante la pandemia por Covid-19. [Psychological impact on Mexican university students due to confinement during the Covid-19 pandemic]. Preprint, 644(1), 17. https://doi.org/10.1590/SCIELOPREPRINTS.756

Gonzalez, T., de la Rubia, M. A., Hincz, K. P., Comas-Lopez, M., Subirats, L., Fort, S., \& Sacha, G. M. (2020). Influence of COVID-19 confinement in students performance in higher education. 1-25. https:// doi.org/10.35542/osf.io/9zuac

INEGI. (2019). Medición de pobreza 2008-2018, Estados Unidos Mexicanos. [Poverty Measurement 2008-2018, United Mexican States]. https://www.coneval.org.mx/Medicion/PublishingImages/Pobreza_2018/Seri e_2008-2018.jpg

ITU. (2017). ICT Develepment Index 2017. Measuring the Information Society Report 2017. https://www.itu.int/net4/ITU-D/idi/2017/index.html\#idi2017economycardtab\&MEX

Marinoni, G., Land, H. Van, \& Jensen, T. (2020). The impact of Covid-19 on higher education around the world. IAU Global Survey Report (International Association of Universities (Ed.)). https://www.iauaiu.net/IMG/pdf/iau_covid19_and_he_survey_report_final_may_2020.pdf

Martínez-Garcés, J., \& Garcés-Fuenmayor, J. (2020). Competencias digitales docentes y el reto de la educación virtual derivado de la covid-19. [Digital teaching competencies and the challenge of virtual education derived from covid-191]. $\begin{array}{llll}\text { Educación } y & \text { Humanismo, 22(39), 1-16. }\end{array}$ https://doi.org/10.17081/eduhum.22.39.4114

Mcmillan, J., \& Schumacher, S. (2005). Investigación Educativa. [Educational Research]. At Investigación educativa. Pearson Addison Wesley. https://desfor.infd.edu.ar/sitio/upload/McMillan_J._H._Schumacher_S._2005._Investigac ion_educativa_5_ed..pdf

OCTS. (2019). Informe de coyuntura No 06: Se expande la educación superior a distancia en Iberoamérica, aunque es todavía incipiente. [Conjuncture Report No 06: Distance higher education is expanding in Ibero-America, although it is still incipient]. http:/ /octs-oei.org/coyuntura/coyuntura06.pdf

Pedró, F. (2020). Covid-19 y educación superior en América Latina y El Caribe: Efectos, impactos y recomendaciones políticas. [Covid-19 and higher education in Latin America and the Caribbean: Effects, impacts and policy recommendations]. Análisis Carolina, 36, 1-15. https://doi.org/https://doi.org/10.33960/_AC_36.2020 La

Pereira Pérez, Z. (2011). Los diseños de método mixto en la investigación en educación: Una experiencia concreta. [Mixed method designs in educational research: A concrete experience]. Revista Electrónica Educare, 15(1), 15-29. http://www.revistas.una.ac.cr/index.php/EDUCARE/article/view/867

Prokopenko, I., \& Berezhna, S. (2020). Higher Education Institutions in Ukraine during the Coronavirus, or COVID-19, Outbreak: New Challenges vs New Opportunities. Revista Romaneasca pentru Educatie Multidimensionala, 12(1Sup2), 130-135. https://doi.org/10.18662/rrem/12.1sup2/256 
Rangel Baca, A., \& Peñalosa Castro, E. A. (2013). Alfabetización digital en docentes de Educación Superior: construcción y prueba empírica de un instrumento de evaluación. [Digital literacy in Higher Education professors: construction and empirical testing of an assessment instrument]. Pixel-Bit Revista de Medios y Educación, 43, 9-23. https://doi.org/10.12795/pixelbit.2013.i43.01

Rodríguez, M., \& Mendivelso, F. (2018). Diseño de investigación de Corte Transversal. [Cross-sectional research design]. Revista Médica Sanitas, 21(3), 141-146. https://doi.org/10.26852/01234250.20

Sánchez, M., Martínez, A., Torres, R., de Agüero, M., Hernández, A., Benavides, M., Rendón, V., \& Jaimes, C. (2020). Educational challenges during the covid-19 pandemic: a teachers' survey at UNAM. Revista Digital Universitaria, 21(3), 1-24. https://www.revista.unam.mx/wp-content/uploads/a12.pdf

UACH. (2019). Estadística Básica 2019. [Basic Statistics 2019]. https://uach.mx/assets/media/publications/2017/10/143_agendaestadistica/Estadistica-2019-2020.pdf

UNESCO. (2015). Quindgao Declaration. (2015). Seize digital opportunities, lead education transformation. https://unesdoc.unesco.org/ark:/48223/pf0000233352

UNESCO. (2020a). COVID-19 Impact on Education. Education: From disruption to recovery. https://en.unesco.org/covid19/educationresponse

UNESCO. (2020b). COVID-19 y educación superior: De los efectos inmediatos al día después. [COVID-19 and higher education: From immediate effects to the day after]. At Unesco. http://www.iesalc.unesco.org/wpcontent/uploads/2020/04/COVID-19-060420-ES-2.pdf

Vera Noriega, J. A., Torres Moran, L. E., \& Martínez García, E. E. (2014). Evaluación de competencias básicas en TIC en docentes de educación superior en México. [Evaluation of basic ICT competencies in higher education teachers in Mexico.]Pixel-Bit. Revista de Medios y Educación, 44, 143-155. http:/ / www.redalyc.org/articulo.oa?id=36829340010

WHO. (2020). WHO Director-General's opening remarks at the media briefing on COVID-19 - 1 April 2020 (p. 1). https://www.who.int/dg/speeches/detail/who-directorgeneral-s-opening-remarks-at-the-media-briefing-on-covid-19---1-april-2020 